\title{
New service development in high tech sectors: a decision making perspective
}

Citation for published version (APA):

van Riel, A. C. R., \& Lievens, A. (2003). New service development in high tech sectors: a decision making perspective. METEOR, Maastricht University School of Business and Economics. METEOR Research Memorandum No. 013 https://doi.org/10.26481/umamet.2003013

Document status and date:

Published: 01/01/2003

DOI:

10.26481/umamet.2003013

Document Version:

Publisher's PDF, also known as Version of record

\section{Please check the document version of this publication:}

- A submitted manuscript is the version of the article upon submission and before peer-review. There can be important differences between the submitted version and the official published version of record. People interested in the research are advised to contact the author for the final version of the publication, or visit the DOI to the publisher's website.

- The final author version and the galley proof are versions of the publication after peer review.

- The final published version features the final layout of the paper including the volume, issue and page numbers.

Link to publication

\footnotetext{
General rights rights.

- You may freely distribute the URL identifying the publication in the public portal. please follow below link for the End User Agreement:

www.umlib.nl/taverne-license

Take down policy

If you believe that this document breaches copyright please contact us at:

repository@maastrichtuniversity.nl

providing details and we will investigate your claim.
}

Copyright and moral rights for the publications made accessible in the public portal are retained by the authors and/or other copyright owners and it is a condition of accessing publications that users recognise and abide by the legal requirements associated with these

- Users may download and print one copy of any publication from the public portal for the purpose of private study or research.

- You may not further distribute the material or use it for any profit-making activity or commercial gain

If the publication is distributed under the terms of Article $25 \mathrm{fa}$ of the Dutch Copyright Act, indicated by the "Taverne" license above, 


\title{
New service development in high tech sectors: a decision making perspective $\mathrm{e}^{\#}$
}

\author{
Allard C.R. van Riel* \\ Maastricht University, Maastricht, The Netherlands and \\ Annouk Lievens \\ University of Antwerp, Antwerp, Belgium
}

The authors wish to gratefully acknowledge the helpful comments of the editor, anonymous reviewers and professor Christophe Boone of the University of Antwerp.

\footnotetext{
\# This article is based on Chapter 3, "New Service Development in Mobile Telecommunications", in Van Riel, Allard C.R (2002), Effective Decision Making in the High Tech Service Innovation Process, Doctoral Dissertation, Maastricht University, Maastricht, Datawyse/Maastricht University Press.

* Corresponding author. Maastricht University, Faculty of Economics and Business Administration, Department of Marketing, P.O. box 616, 6200 MD Maastricht, The Netherlands. Phone: +31 433883778 Fax: +31 433884918 E-mail a.vanriel@mw.unimaas.nl
} 


\section{New service development in high tech sectors: a decision making perspective}

Keywords Decision-making, innovation, new service development process, mobile telecommunication services, information processing, case study research

Abstract Many service companies active in high tech sectors have implemented largely decentralized decision architectures in their innovation processes. This is done to improve responsiveness under extremely dynamic and uncertain business conditions. As a consequence of the empowerment of decision-makers at the product management level, the success of the New Service Development (NSD) process will increasingly depend on individual product managers' information processing and decision-making performance. The present study investigates antecedents of decision-making effectiveness in the high tech NSD process, and reports on a case study performed in the mobile telecommunication services industry. NSD project managers' unique task conditions are articulated, and some antecedents and moderators of effective decision-making are identified in a study of four innovation projects. Findings are integrated in a theoretical framework. The study reveals the crucial role of decision-makers' flexible use of various cognitive styles, their proactive attitude, and their capability to mentally represent innovation interfaces with the customer, the technology and the firm. Managerial implications and suggestions for further research are provided. 


\section{Introduction}

Innovation is playing an increasingly important role in high tech service sectors. Service firms are confronted with rapid technological developments, fast changes in customer requirements, and hypercompetition, leading to exceedingly short product life cycles (Bogner and Barr, 2000; D'Aveni, 1994, 1995). Survival chances and profitability of these firms have come to depend increasingly on their capability to innovate fast and successfully (Lehmann, 1997). However, many new service development (NSD) projects are less than successful (Johne and Storey, 1998), and fail to meet expectations with respect to financial performance or customer value creation (Cooper and Edgett, 1996). At the same time, the necessary investments are often very high.

An important stream of academic research has emerged in response to the challenges of service innovation, focusing on the identification of innovation success factors. Based on the concept of a SWOT analysis, De Brentani and Ragot (1996) distinguish between internal success factors, related to the strengths and weaknesses of the firm, e.g. NSD competence (Menor et al., 2002) and the organization or design of the firm's NSD processes (Froehle et al., 2000; Storey and Easingwood, 1993; Tax and Stuart, 1997) on the one hand, and external success factors, features of the NSD related to opportunities and threats in the environment on the other. Whereas external success factors are immediately perceived by the customer as benefits of the new service, the internal factors affect consumer benefits only indirectly (Storey and Easingwood, 1993). So far, the majority of studies has focused on the identification of external factors (Edvardsson et al., 1995), such as the fit between customer needs and benefits of the service offer, and the fit between the new service and an existing product portfolio. A number of studies have also focused on the contribution of supporting processes inside the innovating organization, but external to the NSD process, such as the marketing, sales and distribution functions (Cooper and Kleinschmidt, 2000; Dutta et al., 1999; Storey and 
Easingwood, 1993, 1996, 1998). In some research on internal success factors, evidence was found that the amount and quality of conducted market research, development speed, technological advantage and synergy between the new service and the organization contribute to the success of financial service innovations (Storey and Easingwood, 1993). Furthermore, in a research stream focusing on the relationship between innovation performance and organization design, an appropriate organization structure and decision architecture (Burns and Stalker, 2001; Cooper, 1992; Tushman and O'Reilly III, 1996) and an appropriate design of the innovation process (Cooper and Edgett, 1996; Storey and Easingwood, 1993; Sundbo, 1998) may contribute substantially to innovation success.

In accordance with the findings of the latter stream of research, companies active in very dynamic industry sectors, such as high tech services, now generally employ organic (Burns and Stalker, 2001) and flexibility oriented organization structures (MacCormack et al., 2001), and have implemented highly decentralized decision architectures. As a result, the innovative performance of these firms now depends increasingly on the ability of individual product managers to exert control over new service development (NSD) projects: the quality of decision-making inside individual NSD projects thus plays an increasingly important role in innovation success (Ahlert and Evanschitzky, 2002; Jensen and Harmsen, 2001). Decisionmaking during the high tech NSD process is notoriously difficult as a result of the intangibility of the product, extreme levels of uncertainty and great complexity. It can therefore be expected that improvements made with respect to decision-making performance in the NSD project will substantially affect innovation process performance (Cyert and March, 1992; Shapira, 1997; Simon, 1997) and as a result ultimately innovation success rates (Cooper and Edgett, 1996; Storey and Easingwood, 1993). Very little research has been devoted to understanding managerial decision-making during the service innovation process in general (Martin and 
Horne, 1995), and even less in the high tech service sector (Froehle et al., 2000). The research question guiding the present study will therefore be:

What are role and antecedents of decision-making performance in the high tech NSD process?

The aim of the present paper will be to identify antecedents of effective decision-making at the level of individual NSD project managers.

The article is structured as follows. To study facilitators and inhibitors of effective decision-making in the NSD process (cf. Stuart and Tax, 1996) it was decided to conduct a case study research according to guidelines proposed by Eisenhardt (1989). Hence, a preliminary conceptual framework is first constructed for the empirical study, and some research questions are derived in a review of the literature. Second, in a methodological chapter an appropriate design is chosen and developed. The mobile telecommunications service business was chosen as an adequate example of a hypercompetitive and extremely dynamic industry. Since features of an industry's macro-environment will affect the organization of the innovation process (Judge and Miller, 1991) and the task conditions of the decision-makers, first a short analysis of the industry and the focal company are presented. Based upon the research questions theoretically useful cases were selected. Then the case study findings are presented. Based upon these findings a number of propositions are developed. Next, research and managerial implications of the findings are discussed. Finally, limitations of the study and a number of suggestions for further research are presented.

\section{Building a preliminary framework}

Confirming the importance of issues internal to the NSD process are some recent studies pointing at the critical role communication and information processing play in NSD project success (Lievens, 1996; Lievens and Moenaert, 2000; Moorman, 1995). Rapid technological change and turbulence in the marketplace affect decision-makers' information requirements as 
well as the availability of information, and create a need for rapid decisions. For the purpose of this study, decision-making at the level of the product manager is preliminarily conceptualized as the activity of processing information into actions, that control speed, cost and quality of a particular NSD project (cf. Teale et al., 2003).

The core activity of decision-making is generally conceptualized as rational choice (Von Neumann and Morgenstern, 1947); from a number of alternative options the decision-maker selects the alternative that maximizes (Schoemaker, 1982) or satisfices (Simon, 1997) expected utility. In the actual practice of managerial decision-making, however, limited amounts of highly unstructured information are processed against a background of the decision-maker's prior knowledge in order to define the decision problem, set the objectives, construct alternative options, and finally make a choice. Little is understood with respect to each of these issues in the NSD process. A first research question will therefore focus on developing an understanding of what rational choice could mean in the context of the NSD process and how managers see its role in relation to innovation success:

1. How do product managers view effective decision-making in the NSD process and how is the product managers' decision-making performance related to NSD success?

Very little is known about the extent to which decision-makers make use of prior - often tacit knowledge and experience (cf. Behara, 2000), and how they process information under the unique circumstances occurring in the high-tech NSD process. The role of information and prior knowledge therefore needs to be further clarified:

2. What are the roles of information and prior knowledge in NSD related decision-making? It is also unclear how unique the task conditions are, how exactly they pose bounds on decisionmakers' rationality (March, 1978) and by means of which decision strategies (Payne et al., 1990) managers overcome these bounds. A third research question that will guide our study will therefore focus on the task conditions: 
3. Which factors can be distinguished in their task environment that facilitate or inhibit effective decision-making in the NSD process?

The fourth research question will guide our investigation of the strategies used by decisionmakers to adapt to various circumstances:

4. Which decision strategies are used to overcome the conditions encountered in the NSD process?

The research questions are summarized in the preliminary theoretical framework presented in Figure 1.

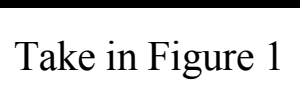

\section{Methodology and research design}

It was decided to use a case study research to investigate issues internal to the high tech NSD process that affect decision-making effectiveness. This decision was based on a number of considerations. First, case study research is particularly appropriate when there is little or no empirical research available on the topic (Bonoma, 1985), i.e. when the study is of an exploratory nature. This is essentially the case with respect to the issues surrounding decisionmaking effectiveness in the NSD process. Second, it is considered appropriate when there is a strong interrelationship between the phenomenon under scrutiny (decision-making effectiveness) and its immediate environment (the high-tech service innovation process), whereas it is difficult to separate the two (Bonoma, 1985; Yin, 1993, 1994).

Case studies can be conducted in a number of ways (Meredith, 1993; Yin, 1993, 1994). Since very little explicit theory about high-tech service innovation decision-making was available, it was decided not to use a merely deductive method, whereby the case study is used to illustrate the plausibility of extensions of existing theory (cf. Boone, 2000). Instead, a method is used, proposed by Eisenhardt (1989) and Lievens et al. (1999), that was designed to allow the 
construction of a theoretical framework from observations by means of induction (Judd et al., 1991). Propositions are derived from the case study research findings (Bourgeois III and Eisenhardt, 1988). To increase the validity of newly introduced constructs, a heuristic method of iterative concept development is used (Kerlinger, 1986). A case in case study was developed in order to investigate the high-tech service innovation process. The unit of analysis is the individual NSD project.

\section{Sampling}

In the choice of cases, a purposive sampling strategy was pursued (Eisenhardt, 1989). Cases needed to be selected in such a way that their investigation would optimally contribute to the understanding of the interrelationships between task conditions, decision strategy and the probability with which decisions contributed to a successful new service development project. Selection criteria were based upon two dimensions. In order to allow the identification of factors distinguishing between successful and non-successful projects, i.e. projects leading to a successful or a non-successful service, the extent to which the company considered the resulting new service to be successful was selected as a first dimension. By asking two experienced managers to select the successful and unsuccessful cases from a wide range of both supporting and core services, it was assured that they used a balanced set of performance indicators (Easingwood and Percival, 1990; Easingwood and Storey, 1993), and did not treat new service performance as a single dimension (Cooper and Kleinschmidt, 2000).

Since a relationship was sought after between NSD success and the task conditions, we furthermore tried to find a factor that would determine the task conditions. Decision-makers' task conditions were expected to vary substantially with the extent to which the new services could be considered new. As a second dimension we therefore decided to use the continuum between services that were new to the organization, but not to the industry (so-called me-too 
innovations) and services that were entirely new to the market as well as to the organization (really new services)(Lovelock, 1984). In Figure 2 the case study design is visualized.

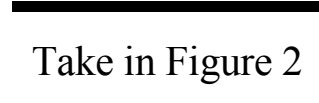

The mobile telecommunication services industry in the EC: an analysis

The telecommunication services industry is considered one of the most dynamic sectors of the European economy. It was therefore decided to conduct the study in a company active in this sector. In the following it is investigated how and to what extent industry characteristics affect the task conditions of NSD project managers.

\section{Regulatory environment and competitive situation}

As a result of partial deregulation of national telecommunication markets in the European Community (EC) and the privatization of state-owned telecommunications providers, at present limited numbers of operators are active in each country. National markets are thus characterized by intense rivalry between small numbers of firms. This rivalry directly affects the working conditions of the manager, as it puts substantial pressure on the speed with which they bring new products to market (Kessler and Chakrabarti, 1996). Although no universal empirical support has been found for the relationship between faster product development and competitive advantage (Bayus et al., 1997; Ittner and Larcker, 1997), a number of potential benefits are associated with accelerated product development and a faster speed-to-market in very competitive markets. Additional pressure is caused by the recent decisions of national governments in the EC to auction licenses for the use of new frequency ranges, needed for highbandwidth communications, at unprecedented prices. Communication providers were virtually obliged to make excessive investments in order to acquire these licenses. To take advantage of these licenses they are now obliged to upgrade their network infrastructures. This has led to 
huge debts, strongly affecting telecommunication stock performance, threatening the survival of some operators, and increasing the pressure on top management to use resources effectively. This is also leading to pressure on NSD managers to improve effectiveness.

\section{Changing markets, customer requirements and hypercompetition}

The market for telecommunication services has changed radically over the past decade. Initially, the number of new users of basic mobile communication services grew very rapidly, but in the EC the market size now approaches saturation. Second, consumption patterns and customer requirements change continuously, and services rapidly become obsolete, resulting in increasingly short product life cycles. Due to the increasingly global nature of the telecommunications industry, ideas spread rapidly and a swift imitation or adaptation of successful products has become a universally adopted strategy. This results in a hypercompetitive marketplace, making a fast and efficient new service development process an essential competitive competence. All operators in the European market are therefore highly innovative and dynamic companies, with a firmly competitive culture. This directly affects the task conditions of the decision-makers active in the NSD process.

\section{Technological change and competing standards}

Technological change contributes dramatically to the dynamics of this technology-driven, industry. Developments in the electronics and software industries are reminiscent of Schumpeter's waves of creative destruction (Schumpeter, 1934), paving the way for all sorts of entirely new services. Concurrent developments affecting the industry are media convergence and the integration of mobile phones and handheld computers into so-called wireless digital assistants (WDA). Furthermore, new communication technologies and protocols compete in order to become global standards. New regulations are introduced on a regular basis. These changes contribute to the ambiguity, uncertainty and complexity of the macro environment and of the task conditions of decision-makers alike. 


\section{Consolidation}

The industry is currently characterized by substantial consolidation activity. This causes changes in organizational settings, rapid turnover of top management and frequent radical changes in strategic objectives, and indirectly affects decision-makers at a product level. Frequent shifts in the competitive landscape and organization structure create a need for up-todate information and flexibility.

\section{The research site}

Some features of the focal company are relevant for a good understanding of how the innovation process is embedded in the organization. The focal company is a subsidiary of one of Europe's former state-owned telecommunications companies, and like most of its competitors a relatively new player. Founded only a few years ago, managers and staff are young, highly dynamic, moderately inexperienced, and enthusiastic workers with a proactive attitude towards learning. Partially due to the relatively short existence of the subsidiary, partially due to industry dynamics, the organizational structure had not crystallized at the time of the case study and was considered flexible and being adapted to the changing requirements. A major choice, however, having had an important effect upon the organization of the innovation process, was the decision to use an adapted stage-gate process model for new service development (Cooper, 1992). This provided the innovation process with a comparatively structured framework. The adapted stage gate process model allows for the coordination of parallel development activities in different functional departments, all relating to the same innovation. Thus product development time is reduced, albeit at the cost of greater complexity. The gains in terms of development speed were considered more important, however, than the disadvantages related to an increase in complexity. 


\section{The cases}

The objectives of the research as well as selection criteria for the innovation projects were then presented to two senior staff members of the focal company. They selected four cases according to the criteria and were asked to provide the researchers with access to company documentation with respect to the projects and staff involved in the respective projects. The first project (project I, service new to the organization, but not to the world, successful) was the development of a voice- and fax mail service. The unique benefit of the service consisted in offering the consumer the possibility to retrieve, at a moment of his or her own choice, voicemail messages and faxes having arrived, while the mobile phone was switched off or when he or she was unavailable. This service had already been commercialized successfully by competitors, between six months and a year before the establishment of the focal company. As this was a me-too innovation, there was tremendous pressure from top management, to get the service fast on the market. At the same time, the service had to offer a high degree of userfriendliness, if possible more than incrementally improving on existing offers from the competition. It was one of the first new services the company developed.

The second service innovation that was studied (project II, service new to the world, successful) was the development of an entirely new tariff structure and corresponding invoicing system. Instead of invoicing customers per fixed time unit, which is common practice among mobile communication service providers, the company launched the option to be invoiced by a fixed debit amount. The benefit for the consumer would be the freedom to spend a previously agreed amount of credit on his or her own choice of services. The invoicing system was highly innovative and its benefits to the consumer had to be promoted heavily, since nothing comparable existed.

The third innovation (project III, new to the organization not to the world, not successful) related to the development of a supplement to existing mobile services. The new 
service made it possible for the subscriber to display the original caller ID on his or her phone, of a caller that was transferred via another number. The basic technology needed for the supplementary service was already embedded in the network design. Service development therefore consisted of a rather technical implementation process within the company, assuring compliance to legal and technical standards. Complexity was very high, and although the service was implemented successfully in terms of the technological and regulatory requirements, it was not considered a commercial success. The service was originally developed in compliance with a large contract with an important business customer that did not allow any deviations from the original specifications.

The last project being selected (project IV, new to the world, not successful) was the development of a premium branded service offer. The idea behind the new service package was to introduce an executive communications package that typically included the most sophisticated communication device on the market, and offered all possible advanced options, most of which were already available to other customers against extra charges. There was strong pressure from the parent company to develop this package, as the idea was originally theirs. However, the subsidiary had other priorities at that moment, such as developing a broad customer base and positioning their own still rather unknown brand. This resulted in a bad match between the subsidiary's own objectives and operations and the new service. A summary of the distinctive features of the four innovation projects can be found in Table 1 .

Take in Table 1

\section{Data collection and processing}

Several data collection methods were combined to increase construct validity (Yin, 1994). Desk research involved the examination of company documents relating to the four innovation projects, such as the original service specifications and progress reports, marketing materials that had been used for their commercialization, the company website, publicly available 
information such as the mission statement, financial year reports and press announcements. This was done with purpose of developing insight in the new service development and marketing strategies of the company, as well as in the position of the four new services in the total offer. In the second place, an archive of newsletters from mobile telecommunications providers active in various national markets was studied. Most mobile telecommunication service providers distribute newsletters to their subscribers either in print or via the Internet, and use them to introduce new technologies and services and explain their sometimes highly complicated benefits. The purpose of studying them was to develop a better appreciation of the industry and its dynamics.

After an understanding of the company, its relative position in the industry, and the prevailing macro-environmental conditions had been developed, field research was conducted. In-depth interviews were conducted with decision-makers involved in each of the innovation projects, with a technical manager involved in a number of projects, as well as with two top managers. These interviews were conducted in as open a format as possible. In order to increase the reliability of the field study, an interview guide was constructed and used for all interviews. The themes included in the interview guide were based upon the research questions, a selection of relevant managerial decision-making literature (Hammond, 1996; Hastie and Dawes, 2001; March, 1999; Weick, 2001a) and writings on service innovation. Most interviews lasted between an hour and ninety minutes. The interviews were transcribed in their entirety and subsequently studied by the researchers in terms of their content, with the double objective of identifying recurring themes on the one hand, as well as capturing the differences in terms of task conditions and innovation performance between the four projects on the other hand. Additionally, the research team met on a regular basis with key informants at the company, to discuss the progress and findings of the study. Finally, the interviewees were confronted with the theoretical model that was developed during a feedback workshop, and their comments were 
used for further refinement of the propositions. This procedure was used with the purpose of further increasing the internal validity of the model (Bonoma, 1985).

\section{Results}

\section{Effective decision-making in the NSD}

With the purpose of developing a better understanding of the nature of the problems the decision-makers experienced in the high-tech innovation process, they were asked to describe what they considered effective decision-making, and to articulate the unique circumstances and challenges they encountered during high-tech service innovation projects.

From the interviews it became clear, that in each project large numbers of interrelated and interdependent decisions have to be made. According to the decision-makers, due to the parallel organization of the new service development process, decisions were often made that required knowledge about other choices, made only later on in the process. As a result of the interdependency and interrelatedness of decision outcomes the 'expected utilities' of options of one decision would often depend on other choices later on in the project. Hence, according to the interviewees, it is often very difficult to judge the 'quality' of individual decisions, or their individual contribution to project performance. Even ex post facto it often remains difficult to judge whether or how any particular decision contributed positively to the success of the NSD project. One manager formulated this dilemma of rational decision-making as follows:

"Often you simply have to make a decision, and as a result of the uncertainty and complexity you simply cannot decide which option is best. No one ever could. However, for the sake of progress, you simply make a decision and later on, when things have become a bit clearer you make adjustments as you go".

Consistent with the experience of the managers, but in contrast with most theories of rational decision-making, where it is, at least in retrospective, possible to calculate for each particular decision which option maximized the decision-maker's utility (Schoemaker, 1982; Von 
Neumann and Morgenstern, 1947), the concept of 'effective decision-making' is introduced. Since the quality of individual decisions cannot be assessed in this highly complex context, 'effective decision-making' is defined as making decisions in such a way, that decisions - on average - contribute positively to maintaining control over the process, i.e. maintaining an appropriate balance between costs, speed and quality of the new service development process. In this sense, the effectiveness of decision-making is positively related to the performance of the NSD process and ultimately to new service success. The level of analysis of the study thus moves from the rationality of individual decisions to the effectiveness of the process of decision-making as a whole.

\section{The role of prior knowledge}

The interviewees thus acknowledged that as a result of their difficult task conditions, nobody would make 'the right decisions all the time'. At the same time, however, they stressed that what they called 'their expertise and understanding' played an important role in helping them to make decisions effectively, or as one manager expressed it:

'We are the experts' (in the innovation project) 'and there is simply no one else who could actually make adequate decisions'.

Based upon this observation, recurring in each of the interviews, it is proposed:

P1: A positive relationship will exist between the extent to which product managers possess expertise and decision-making effectiveness.

Having identified decision-makers' 'expertise' as an important antecedent of decision-making effectiveness, the decision-makers were subsequently asked to explain what they thought their expertise consisted of. They did not regard expertise in a traditional sense, as a domain related expertise or skill. What they referred to was actually a multidisciplinary proficiency in their job as managers of high-tech NSD projects. In order to get a better grip on this highly complex concept, we asked for their interpretation of expertise. It became clear that what they referred to, 
was their unique grasp of the coherence between the 'the features of the new service', 'the organization of the new service development process' as it was practiced in the focal company, and various interfaces of the new service with relevant dimensions of reality. After further probing into the concept of expertise, it became apparent that the interviewees thought, that the extent to which the decision-maker possessed an adequate mental image of the new service itself largely determined their decision-making effectiveness. This mental image of the new service was delimited by its interfaces or contact points with the organization, the customer and the market, the technology and the regulatory environment. In the following these interfaces will be discussed, as the decision-makers described them, in some more detail. Decisionmakers' mental image of the new service and its four interfaces are graphically represented in Figure 3.

\section{Take in Figure 3}

\section{Service organization interface}

As a first aspect contributing to an adequate mental representation of the service, the decisionmakers brought up a good understanding of how the new service fit the organization. This insight was deemed especially important for a smooth coordination of the innovation project. The decision-makers mentioned that a profound understanding of the organization structure, its culture, its dynamics and the prevalent resource allocation mechanisms, which they got to know during previous innovation projects, was very helpful in 'picturing' this interface accurately. As there was a need for fast decisions, their understanding of the organizational decision process, obtained in previous projects, was considered very valuable. At the same time, they recognized that a good understanding of the service-organization interface was what they lacked most in the early projects and what made a timely completion of their first projects very difficult. An accurate mental image of the service-organization interface contributed to a realistic representation of 
'what is possible and feasible'.

Having this realistic mental image of the organizational possibilities, with respect to the innovation, helped them create more relevant decision options faster, which in turn helped them making the actual decisions faster. Their experience with the innovation-organization interface taught them not necessarily 'which option to choose', but rather what the relevant options were. In short, they deemed a good understanding of the service-organization interface very advantageous for the smoothness of the coordination of the projects and the speed of decisionmaking. Because organizations vary substantially with respect to the emphasis they put on the different information processing activities (Moorman, 1995), a good understanding of the limitations of organizational information gathering and dissemination activities will also help managers decide which supplementary information they need and how to obtain this, in order to reduce the uncertainty more effectively. It is therefore hypothesized that:

P2: A positive relationship will exist between the extent to which product managers possess knowledge of the service-organization interface and decision-making effectiveness.

Insight in the service-organization interface was largely based on experience acquired during previous projects. During the interviews, most managers explicitly contrasted their experience with the service-organization interface, with respect to its usefulness, with for example the technical knowledge they had obtained in previous projects. They stated that it was often very difficult to use any of the technical knowledge learned in previous projects, because the services they developed had often very little in common with respect to the technology. They also noted that 'technology moves forward with the speed of light', rapidly making their experience in that area obsolete. All confirmed that the service-organization interface was the domain they actually learned most in. 


\section{Service-customer interface}

Although high-tech service innovation is often considered largely technology driven, all decision-makers stressed that a firm customer-orientation and a good understanding of customer requirements were necessary conditions of effective decision-making in the NSD process. Consequently, the second interface deemed important by all decision-makers was the interface between the new service and the customer. The decision-makers contended that they made many of their decisions, whilst keeping in mind their private, tacit, and comprehensive understanding of customer requirements, or as one manager called it:

\section{'The feeling how the customer behaves and moves'}

In the focal firm, the need for speed often did not allow for extensive project related market research, and as a result, this 'understanding of the customer' appeared to play a key role in all projects. In successful projects, 'customer knowledge' acted as a success factor helping the project managers to make the right decisions. In the unsuccessful projects, however, such as projects III and IV, the decision-makers' customer knowledge acted as an 'early warning sign' or as an indicator of potential problems. Especially in decisions with respect to the service developed in project III, the project manager was not allowed to use this customer knowledge, as the service was developed according to specifications that had been laid down in an inflexible contract. It is hypothesized accordingly:

P3: A positive relationship will exist between the extent to which product managers possess knowledge of the service-customer interface and decisionmaking effectiveness.

When probing into the origins of this 'customer knowledge', it was noticed that decisionmakers, most of them having an academic background in marketing, generally agreed that there are a number of problems with conventional market research in the area of high-tech new service development. In the first place it was often considered to be too time consuming. In an 
industry where speed to market is assumed to play such an important role in the success of the new services, the trade-off between speed and a higher degree of certainty appeared crucial. In many cases, according to the decision-makers, an increase in speed was considered to largely outweigh a greater degree of certainty. In the second place, in high-tech services consumer tastes and needs evolve very rapidly, and co-evolve with new technologies that become available. It is therefore very difficult to assess with any certainty how consumer needs and requirements will develop. The intangibility aspect of services, especially prominent in hightech services where it is very difficult for the consumer to imagine the service until it is actually there, was also mentioned as a problem contributing to the difficulty of assessing consumer reactions to prototypes of the service. In this context, managers repeatedly said that an intuitive understanding of the 'consumer' and their ability to imagine and anticipate their requirements and possible reactions accurately was an important skill in their function, that would help them make the right decisions. Even when modern or alternative ways of product development are used, such as rapid prototyping and evolutionary development (MacCormack, 2001), whereby the consumer is participating in the product development process, by e.g. testing Beta-versions, an intuitive understanding of the customer will continue to add value through a better anticipation of customer requirements.

The marketing research department of the focal company regularly organized market studies, sometimes at the level of the parent company and sometimes at the level of the subsidiary, thus providing the managers with hard data about general trends and developments in customer requirements. In order to update their representation of 'the customer' the decisionmakers made use of this information, and merged it with their 'intuitive understanding'. Their mental representation of the desires and possibilities of the customer based on their own desires and possibilities, corrected for the fact that they considered themselves 'crazy about telecommunications' and corrected for their own technical proficiency was complemented and 
completed with market information from retailers, the Internet and many other sources. One manager remarked:

'Dealers and retailers, that's where you get your 'feeling' from'.

Decision-makers also said that they made faster sense out of the results of formal market research, the more experience they had in the area:

'The longer you're in business the faster you go'.

This can be explained by the build up of absorptive capacity (Cohen and Levinthal, 1990) or the capacity to correctly interpret and assimilate new information. This absorptive capacity is built up over the years and grows with experience.

Service-technology interface

A third aspect of what the decision-makers called their expertise was technology. More precisely, they referred to their non-technical insight in relevant technological developments, or what we will call the interface between the new service and technology. Clearly, the decisionmakers were not supposed to be technical experts, there were sufficient other people involved in the innovation project with detailed technical expertise. Their technological expertise was the ability to communicate effectively and efficiently with technical experts. They had to integrate their understanding of technological problems and possibilities in their decision-making. It is thus hypothesized that:

P4: A positive relationship will exist between the extent to which product managers possess knowledge of the service-technology interface and decisionmaking effectiveness.

After probing further into the origins of this insight, the managers affirmed that more than in other cases they had to use their communicative abilities to extract the relevant information from the technical staff. They had to adapt to the jargon of the technical staff, translate it or project it onto what they viewed as the 'real human world' of the service innovation. At the 
same time, the accuracy of the mental representation of the service-technology interface depends on the decision-maker's understanding and anticipation of technological developments. A certain affinity and familiarity with information and communication technology was therefore considered a prerequisite of an accurate mental representation of the service-technology interface.

\section{Service-regulations interface}

Another factor mentioned by most decision-makers, was the need to comply with externally imposed regulations and standards. These regulations originated from both the suppliers of the network technology and from governmental regulators. Whereas the three other dimensions for most managers had a positive connotation, implying that better insight would lead to decisions that could contribute positively to the success of the innovation, their understanding of the regulatory environment rather served as a limiting device and better knowledge of the regulatory forces would only lead to a more 'cautious choice of options'. In the view of the decision-makers, the regulatory environment limited, rather than created opportunities. Nonetheless, the managers agreed that their familiarity with the regulations and the extent, to which they somehow understood their logic, helped them making correct decisions more rapidly. It is therefore hypothesized that:

P5: A positive relationship will exist between the extent to which product managers possess knowledge of the service-regulations interface and decisionmaking effectiveness.

For each project the files consisted of many pages of highly technical and legal information. Since they mostly agreed that it was

\section{'entirely impossible to keep up with changes and know all current regulations'}

they would develop an intuitive feeling with respect to the regulations and base most decisions on this intuitive feeling about the boundaries. 


\section{The task environment of the decision-makers}

The interviewees were then asked to describe the factors directly affecting decision-making effectiveness during the NSD process. Three major recurring themes were identified in all recorded accounts, relating to the task conditions. The decision-makers described their decisionmaking effectiveness, or the extent to which they were able to exert control over the process, as most powerfully threatened by the typical combination of dynamic complexity, uncertainty and time pressure they encountered in their work. As a result of further probing, a more detailed picture of these three factors was obtained.

\section{Interactive dynamic complexity}

A first issue that came up in most interviews was the tremendous complexity of most decision problems. The managers specified that the number of issues that had to be dealt with in the decisions was not the only explanation for the problem complexity. Most of the time, they would have to take into account a large number of interdependent issues from multiple disciplines and perspectives. The state of affairs in some of these areas was relatively stable (e.g. organization structure, resources and capabilities), whereas it was in a constant flux of change in other areas (e.g. market, technology and regulatory environment). The complexity was amplified by the fact that most innovation projects in the focal company were not divided into a series of consecutive projects, but rather into a number of interdependent projects that were partially run in parallel. As was already discussed, each decision with respect to one part of the project, in turn affected the available decision options and their valences in other parts. A major challenge for the decision-makers was to make sense out of what has appropriately been called this interactive dynamic complexity (Weick, 2001b). Expertise helped the product managers to reduce the complexity. It is therefore hypothesized: 
P6: An inverse relationship will exist between the perceived level of task complexity and decision-making effectiveness.

P6a: An inverse relationship will exist between the decision-maker's level of expertise and the perceived level of complexity.

After further probing into the nature of the interactive dynamic complexity, the complexity was described as a function on the one hand of the number of issues to be considered, the multidisciplinary nature of the issues, their interrelatedness and their changeability.

\section{Uncertainty}

Permeating all managerial decision-making, but decision-making in high-tech service innovation projects in particular, is a high level of uncertainty. Uncertainty in the innovation project was articulated as the extent to which reliable and detailed knowledge of important issues was not available to the decision-maker at the moment the decision had to be made. Decision-makers admitted that the uncertainty could only be reduced to a certain extent and that relatively high levels would always persist throughout the project. They considered uncertainty in the high-tech service innovation process to be an important trade-off with respect to speed. Most managers were very well aware of this trade-off, as well as of the fact that in high-tech service innovation projects a firm amount of residual or irreducible (Hammond, 1996) uncertainty is inevitable. At the same time, perceived uncertainty was considered a major threat to effective new service related decision-making (Daft and Lengel, 1986; Tushman and Anderson, 1986), whereas expertise helped them to reduce the uncertainty. Consequently, it is hypothesized:

P7: An inverse relationship will exist between perceived levels of uncertainty and decision-making effectiveness.

P7a: An inverse relationship will exist between the decision-maker's expertise and the perceived level of uncertainty. 
Factors contributing most to the perceived uncertainty were the novelty of the service in an absolute sense, i.e. its novelty to the world or the market, but also its relative novelty to the organization. Much of their uncertainty was also related to the technology involved. Certainly at the beginning of a project, the nonexistence of reliable information on the precise specifications of the new service, or the precise requirements from the market, the relation between the new service and the existing portfolio of services, the precise technology, regulations etc. caused high levels of uncertainty. In the course of the project, the uncertainty would indeed be gradually reduced in some areas, but it could still increase in other areas, as it was affected by competitive actions, and by changes in technology and regulations or company policy.

\section{Time pressure and stress}

Another phenomenon all managers considered to be threatening their decision-making effectiveness was the combination of time pressure and stress. In industries such as the telecommunication services industry, where services have exceedingly short life cycles, there is often extreme time pressure. Even a small delay in the innovation project can make the difference between a great success and a failure. The circumstance that for the focal company many innovations were me-too innovations even augmented the time pressure. These so-called me-too innovations had already proven successful elsewhere. If the new service had been commercialized in the market where the focal company was active, a fast time to market would decrease the first-mover advantage of directly competing firms. If the innovation had been commercialized in other markets, e.g. by the parent company, the focal company could be the first to introduce the service in their market and thus enjoy a first-mover advantage. In both cases pressure to get the service out as fast as possible was very high.

Decision-makers described the time pressure sometimes in a negative sense, as a 'lack of time'. Time pressure indeed reduces the time available to do project based research, i.e. to collect and process information related to the service under development and thus to reduce the 
task uncertainty. This in itself was considered an important challenge. However, after some probing, it was also acknowledged by the managers that they perceived time pressure as more than simply a lack of time. It was also, more positively, experienced as pressure, which could lead to variable amounts of stress. The decision-makers stressed that they did not necessarily and always experience this as a negative thing, since a certain amount of stress is known to increase creativity and productivity. Severe stress is known to affect judgment quality negatively, however, through a reduction of the consideration set. It is therefore hypothesized:

P8: In high-tech service innovation projects, a curvilinear (inverted u-shaped) relationship will exist between time pressure and decision-making effectiveness.

In the two projects considered to be unsuccessful, another source of stress was detected. Role ambiguity, i.e. the absence of decision authority, where the decision-makers were actually the most knowledgeable employees, was also felt to contribute directly to a feeling of stress.

\section{Decision strategies and the use of information}

Even under the extreme conditions of dynamic interactive complexity (Weick, 2001b), uncertainty, and time pressure surrounding their work, decision-makers continuously have to make decisions, and have to make these decisions in a coherent way, fast and confidently. The purpose of the fourth research question was to identify effective decision-making strategies. Therefore, the managers were asked how they made decisions. Two categories of answers were detected. One category was related to the cognitive skills employed by the managers in order to deal with the challenges in their tasks. The second category had to do with more managerial skills employed to deal with the negative effects of uncertainty, complexity and time pressure.

\section{Cognitive aspects}

The interviewees all affirmed that the difficulty of their task demanded much of their cognitive skills in general. They also agreed that the difficult task conditions could be best dealt with by 
flexibly employing a combination of rational analysis, common sense and intuition. None of the decision-makers had a clear preference for any of the mentioned cognitive styles; all agreed that it was precisely their flexibility in choosing an appropriate style at the right moment that enabled them to deal with the task. They stressed that it was largely a matter of experience to know which decision style should be used best under which conditions, in order to maintain control over the speed and quality of the process.

When we probed further into the appropriateness of the use of different styles, they affirmed that rational analysis was used most appropriately, as far as possible with respect to the relative lack of hard data, in the cases where highly consequential decisions had to be made, e.g. at the gates of the stage-gate process. The process of rational decision-making, associated with the collection of information and an explicit justification of the outcome, although by all decision-makers considered to lead to high quality decisions, was considered the most time consuming of the three styles. For reasons of time pressure and lack of usable data, this style could not be applied all the time, and explicit rational analysis was therefore generally concentrated around the gates. These were also the moments when their decisions had to be justified to top management. All decision-makers perceived these moments as the anchor points of the projects, the moments that complexity and uncertainty were forcibly and temporarily reduced to a relative minimum. These were also the scarce moments of reflection that made them really feel in control of the project.

During the projects information was often very scarce and time pressure and the complexity overwhelming. Insufficient information was often available for any kind of reliable and explicit rational analysis. Furthermore, the turbulence of the environment did not give the decision-makers the impression that they could trust their intuition, either. In such moments they said they would simply use as much common sense as possible. Knowing that they would arrive at one of the anchor points of the projects sooner or later, when they could revise their 
decisions based on a more detailed analysis, they would make use of fast and dirty common sense. Between the anchor points, common sense was considered the option providing the best balance between speed and effectiveness.

A cognitive skill they used at set times was their intuition. They used their intuition to counter the uncertainty and complexity of decision-tasks, when they felt they had a lot of useful personal experience, or when the complexity was such, that it was difficult to articulate arguments. They also used their intuition when decisions had to be made based upon their insight in customer requirements, when there was no time for market research and no hard data were available. Intuition was hardly ever used for arriving at 'hard' decisions at the anchor points, but instead it was regularly applied as a sanity check of the conclusions. They felt that their intuition sometimes functioned like their conscience. Based on these observations it is hypothesized that:

P9: A positive relationship will exist between the extent to which the decisionmaker adapts the cognitive style to the task requirements and decision-making effectiveness.

P9a: The extent to which the decision-maker can successfully adapt the cognitive style to the task requirements will reinforce the effect of expertise on decisionmaking effectiveness.

\section{Psychological aspects}

There were also the individual psychological aspects of the difficulty of the decision-makers' tasks. The interviewees all considered their individual attitude regarding the difficulties of innovation projects, to be an important asset. They reported that it was often a mix of personal and professional ambition to master the complexity, and their attitude to see the difficulties as a challenge rather than as a problem, that actually helped mastering them. As a consequence they would be initiating changes and adaptations, rather than passively adapting to changes occurring 
in the environment. This has been referred to as proactive behavior (Bateman and Crant, 1999) and it is hypothesized that:

P10: The proactive behavior of decision-makers in the NSD process will moderate the perceived difficulty (complexity, uncertainty and time pressure) of the task.

They added in the margin that they could keep up their spirits largely because they felt confident that they could deal with the uncertainty, complexity and time pressure.

The propositions are summarized in Table 4.

Take in Table 4

\section{Construction of a theoretical model}

The purpose of this study was the development of a theoretical framework, linking the unique task conditions of the high-tech service innovation process with antecedents of effective decision-making as expressed in the propositions. A model was constructed, based upon the analysis of the cases, feedback from the interviewees and key-informants, and a match with existing literature. It is proposed to conceptualize the perceived NSD task conditions as mediators (Baron and Kenny, 1986) between the expertise of the decision-makers and the effectiveness of their decision-making. These mediators, as they are the perceived conditions, are affected by the decision-makers ability to reduce them. This effect is represented by the indirect relationship between the antecedents and decision-making effectiveness. It is proposed that they deal with the factors negatively affecting effective decision-making as a result of their expertise on the one hand and their attitude on the other. Their expert insight in four service interfaces also directly affects decision-making effectiveness in the NSD process. A third effect of the expertise is through their choice of an appropriate decision style. A theoretical model integrating the propositions is graphically represented in Figure 3. The lines connecting the constructs in this model represent the propositions. 


\section{Conclusion}

The present study was conducted with the purpose of identifying major determinants of decision-making effectiveness in high-tech NSD projects. In the study, the assumption was made that effective decision-making at the level of the project managers contributes substantially to the success of innovation projects, and ultimately to new service performance. Therefore, the focal points of the study were the decision-makers charged with the supervision of new service development projects.

\section{Theoretical contributions}

The present study has provided a number of invigorating insights. First, our understanding of what constitutes decision-making performance in the NSD process was deepened. As a consequence, the concept of decision-making effectiveness was introduced. Second, the role of prior knowledge was analyzed. Strong indications for a major role of expertise and insight with respect to the interfaces between the new service, the organization, the customer, the technology and the regulations were found. In the third place, the unique task-conditions of the individual decision-makers were analyzed: perceived complexity, uncertainty and time pressure are considered to affect effective decision-making in a negative sense. Finally, an antecedent of effective decision-making was found in the flexible, balanced and appropriate use of various cognitive skills and decision styles: rational analysis, common sense and intuition, driven by the expertise of the decision-makers. On a more psychological level, a 'proactive behavior' of the managers was identified as an important antecedent of dealing successfully with the difficult task conditions. This is not a trivial finding. Since the effectiveness of decision-making depends on making decisions fast, attitude may play an exceedingly important role in situations where knowledge and information cannot provide a 'best option'. Based on the present study, it can 
therefore be concluded that decision-maker's attitude, cognitive skills, an extensive flexibility in the use of these skills, and the presence of expertise determine the extent to which the decisionmakers are able to exert control over the innovation process and to manage projects successfully. The indispensable expertise of the decision-makers is built up over time as a result of their experience on the job and in the industry.

Apart from this, it was observed that the two unsuccessful cases (projects III and IV) shared the common circumstance that the scope of the projects was as one manager remarked 'dictated from above'. This observation seems to confirm the theory of contingency of organizational decision architecture and environmental conditions, proposing that decentralized decision-making, occurring in real-time is preferable in turbulent market environments (Beach and Mitchell, 1978; Moorman and Miner, 1998). In both failed projects, more or less complete and rather rigidly defined new service concepts were handed to the decision-makers, with the task to develop the service. In these cases, the decision-makers did not have the authority to deviate from the original design, or even stop the new service development project if they felt this to be appropriate. In the case of the Caller ID display technology (project III), an important business customer negotiated the inclusion of the service as part of a larger contract. Neither service specifications nor design were negotiable. With respect to the premium brand service package (project IV), the idea came from headquarters. In both cases, the rather rigid delineation of the projects severely restricted the scope of decision options. The decisionmakers lacked decision authority and sufficient resources, notwithstanding the fact that they were the most knowledgeable on the projects and the requirements. As a result, the decisionmakers, not able to identify completely with the projects, and therefore not endorsing the projects as their own, considered themselves to be simply carrying out a project. Both managers reported a strong intuitive feeling, that the projects 'were not right' for the company or the market. They based their feelings on intuitions about the market, customer requirements and 
their understanding of the company, rather than on hard data. Although in both cases the decision-makers were probably the most knowledgeable and most experienced decision-makers the company had, they were not allowed to use their experience and intuitions about the product or the product/market combination.

The two successful cases, on the contrary, had in common that the decision-makers were highly involved in the full design and development of the project and were able and allowed to make use of and integrate their intuitions and common sense with respect to the requirements of the market, the possibilities of the company and the available technology. In the two successful cases, (projects I and II) the decision-makers we interviewed intellectually 'owned' the projects. Based upon this observation, an additional conclusion seems justified, namely that an effective decentralization of innovation related decision-making is a necessary condition of effective decision-making. In a turbulent business environment, the organization should empower the most knowledgeable decision-makers to actually produce the effective decisions they are capable to.

\section{Managerial implications}

Based upon these findings, a number of recommendations can be made to firms in the high-tech services industry. In the first place, it could be recommended to firms to carefully select candidates for the function of decision-makers in charge of high-tech service innovation projects. The task conditions are very demanding with respect to candidates' cognitive skills and their flexibility in using them. Candidates must possess both the necessary skills and the 'proactive attitude' to deal with the combination of dynamic interactive complexity and time pressure and must posses a strong desire to learn in many different disciplines. They also need to possess a non-dogmatic approach to dealing with information and decision-making, in the sense that they must allow common sense, creativity and intuition to support or complement more analytical techniques. Candidates, dogmatically tending to an either purely 'analytical' or 
to an entirely 'intuitive' approach, seem less suitable in this context. With respect to the expertise of candidates, it seems that it takes time to acquire the necessary know-how and therefore it would make sense to select candidates that already had the opportunity to get to know the innovation process and the organization from the inside, rather than external candidates.

In quickly evolving environments, decision-makers need to remain up to date in all areas. In the first place, the organization may therefore consider supporting the decision-makers by introducing an adapted high-velocity information acquisition and diffusion system. The intelligence system should keep track of developments in the market, the competitive environment and the technology and make this information available in real-time to the decision-makers in an efficient way. In the second place, we recommend, that in highly dynamic and complex environments the individual absorptive capacity of the decision-makers be actively maintained. The firm could create favorable conditions by letting the decision-makers attend training seminars and conferences in all relevant disciplines.

An additional condition of effective decision-making was identified in the autonomy of the decision-makers to use their insights and decide about the project, i.e. the extent to which innovation related decision-making is really decentralized. A further recommendation would therefore be to decentralize the decision authority effectively.

\section{Limitations and suggestions for further research}

In the present study, multiple sources of information were combined, while an iterative procedure was followed in order to increase the internal validity of the developed constructs, and the extent to which inferences from the cases correctly represent reality (Yin, 1994). The purpose and scope of the present study were essentially exploratory. Based upon observations a number of propositions were developed, and integrated into a theoretical framework that should be refined and validated in further research. This research could for example consist of a cross 
sectional design, applied to a large sample of high-tech service innovation projects. Valid and reliable measurement instruments need to be developed for many of the constructs brought forward, such as 'effective decision-making' and 'decision-maker expertise', etc. These are complex and latent constructs that should be measured on many levels and in many dimensions.

The study revealed that decision-makers use various cognitive skills and decision styles in order to deal with the difficult conditions in their task. Very little is known, however, about the relative value and validity of the use of analysis, intuition and common sense under these conditions and in what sense or to what extent their effectiveness is moderated by expertise. Research is needed in order to determine how decision-makers adapt their cognitive style to the task conditions and order to develop a better understanding of the trade-off between 'speed' and ‘quality' of various decision styles under real world conditions.

The study also revealed the important role of expertise as a moderator of decisionmaking effectiveness. How expertise, in the present study conceptualized as decision-makers' understanding of the four service-interfaces, originates and is maintained lay outside the scope of the present research. However, a major challenge for organizations in the telecommunication services industry, as well as in many other high-tech service industries, is the high turnover of staff in management functions. Since part of the expertise is tacit, the loss of experienced staff implies the loss of expertise and therefore the loss of an important competitive resource. We know exceedingly little about factors affecting the learning, maintenance and transfer of expertise and knowledge in very turbulent environments. We suggest therefore that research be conducted in this area.

The scope of the research was limited in another sense. We focused on individual key decision-makers. However, decision-makers are part of an extensive information network and depend on external parties, such as the company's suppliers and retail outlets, for information about future developments and trends in technology and consumer behavior. It seems therefore 
worthwhile to study the decision-maker as a node in an information network that connects suppliers, developers, providers and customers. The adequacy of decisions and ultimately the performance of newly developed services will be dependent on the quality of the ties the decision-makers maintain in this network and the extent to which they manage such a network successfully (Burt, 1992). We know very little about the precise structure of these networks. Therefore, the study of innovation decision-makers from a social networking perspective could help discover ways to optimize the network structure and efficiency by finding structural holes.

A limitation brought about by the design of the case research was the fact that fully achieved innovation projects were studied, most of which had been accomplished some time ago. Although it is understandable that companies active in the high-tech services industry are reluctant to share information about projects in progress, for obvious competitive reasons, it would be beneficial with respect to the study of decision-making to conduct longitudinal research over the whole innovation project. This would also permit the collection of less memory- and otherwise biased information, as we now partially had to rely on the representation of facts by the involved managers themselves.

Although the four cases were chosen on the basis of two primary selection criteria, success and novelty, it became clear that the two successful cases shared another common characteristic, which is often related to success. Decentralization of decision authority characterized the two successful cases, whereas decision authority in the two unsuccessful cases was centralized. This on the one hand confirmed the relationship between decentralization of decision authority, but may have disguised the role of other factors.

Finally, an objective assessment of the performance of ICT-based service development projects with respect to perceived quality and the creation of customer value requires the development of reliable and valid measurement instruments. Here, we can only repeat that the currently available service quality scales, developed for services where personal interaction 
between the provider and the consumer plays an important role, are not suitable for high-tech services (Bitner et al., 2000; Dabholkar, 1996; Zeithaml et al., 2000). Research in this area must therefore be considered an absolute requirement for all further high-tech service research. 
TABLES

Table 1: Features of the four new services

\begin{tabular}{|c|c|c|c|c|}
\hline & Project I & Project II & Project III & Project IV \\
\hline Description & Voice- and Fax mail & $\begin{array}{l}\text { Tariff structure and } \\
\text { invoicing system }\end{array}$ & Display caller ID & $\begin{array}{l}\text { Premium branded } \\
\text { package }\end{array}$ \\
\hline $\begin{array}{l}\text { Success } \\
\text { Novelty }\end{array}$ & $\begin{array}{l}\text { Successful } \\
\text { Me-too }\end{array}$ & $\begin{array}{l}\text { Successful } \\
\text { Really new }\end{array}$ & $\begin{array}{l}\text { Not successful } \\
\text { Me-too }\end{array}$ & $\begin{array}{l}\text { Not successful } \\
\text { Really new }\end{array}$ \\
\hline Complexity & High & High & High & Low \\
\hline $\begin{array}{l}\text { Time } \\
\text { pressure }\end{array}$ & High & Medium & Medium & High \\
\hline Control & Decentralized & Decentralized & Centralized & Centralized \\
\hline Benefit & $\begin{array}{l}\text { Offers user more } \\
\text { freedom and } \\
\text { convenience }\end{array}$ & $\begin{array}{l}\text { Offers user more } \\
\text { control over } \\
\text { expenditures }\end{array}$ & $\begin{array}{l}\text { Offers user extra } \\
\text { information and } \\
\text { security }\end{array}$ & $\begin{array}{l}\text { Offers user luxury and } \\
\text { state of the art } \\
\text { technology }\end{array}$ \\
\hline $\begin{array}{l}\text { Target } \\
\text { audience }\end{array}$ & Private and business & Private and business & Business & Business \\
\hline
\end{tabular}


Category Nr. Description:

Antecedent 1 A positive relationship will exist between the extent to which the decisionmaker possesses expertise and decision-making effectiveness.

Antecedent 2 A positive relationship will exist between the extent to which product managers possess knowledge of the service-organization interface and their expertise.

Antecedent 3 A positive relationship will exist between the extent to which product managers possess knowledge of the service-customer interface and their expertise.

Antecedent 4 A positive relationship will exist between the extent to which product managers possess knowledge of the service-technology interface and their expertise.

Antecedent 5 A positive relationship will exist between the extent to which product managers possess knowledge of the service-regulations interface and their expertise.

Mediator 6 An inverse relationship will exist between the perceived level of task complexity and decision-making effectiveness.

Antecedent 6a An inverse relationship will exist between the decision-maker's level of expertise and the perceived level of complexity.

Mediator 7 An inverse relationship will exist between perceived levels of uncertainty and decision-making effectiveness.

Antecedent 7a An inverse relationship will exist between the decision-maker's expertise and the perceived level of uncertainty.

Mediator 8 A curvilinear (inverted u-shaped) relationship will exist between time pressure and decision-making effectiveness.

Antecedent 9 A positive relationship will exist between decision-makers possess expertise and the extent to which they can adapts the cognitive style to the task requirements.

Moderator 9a The extent to which the decision-maker succeeds in adapting the cognitive style to the task requirements will reinforce the effect of expertise on decisionmaking effectiveness.

Moderator 10 The proactive behavior of decision-makers in the NSD process will moderate the perceived difficulty (complexity, uncertainty and time pressure) of the task. 
Figure 1: Preliminary conceptual framework

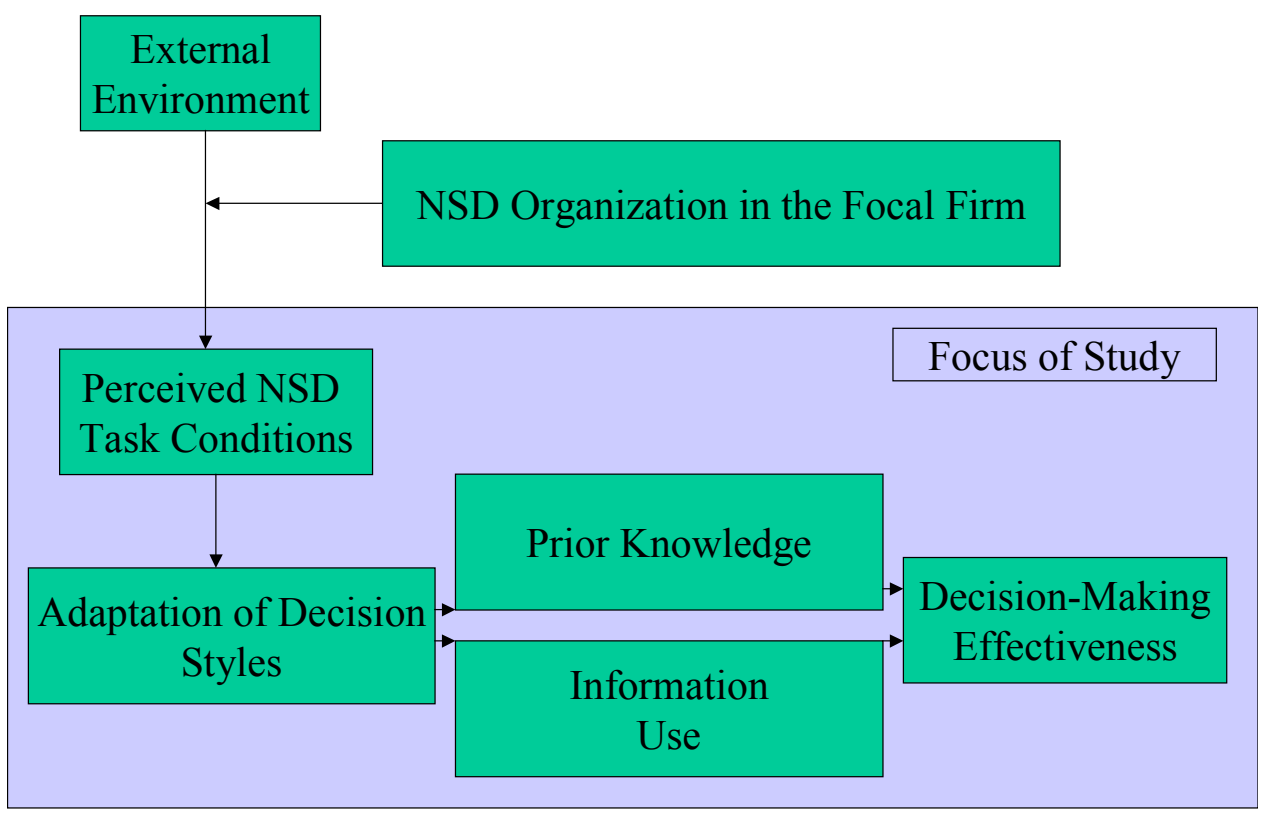


Figure 2: Case study design

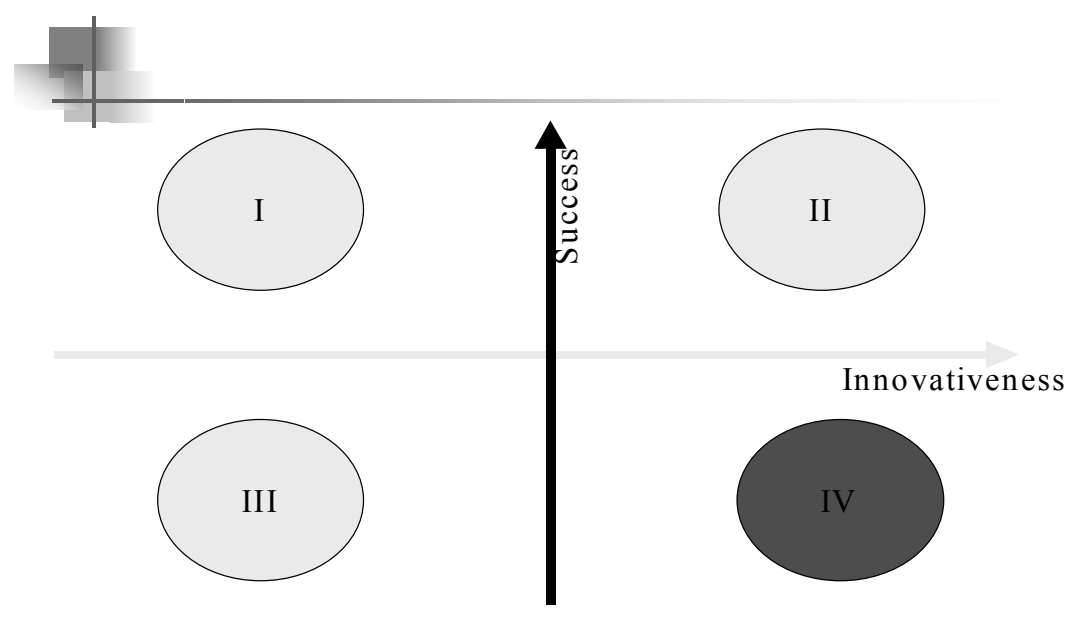


Figure 3: Mental representation of the new service

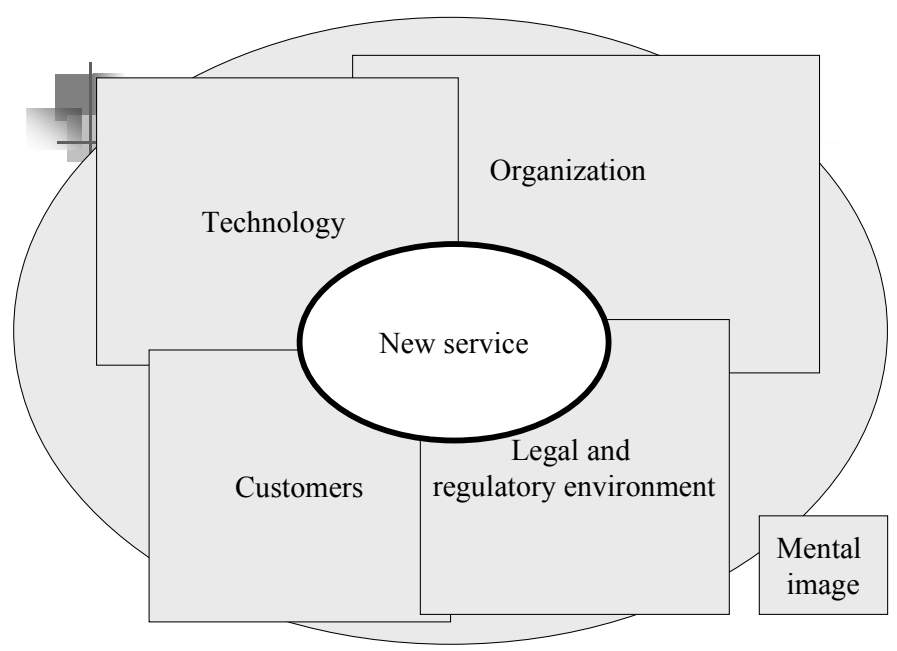


Figure 4: Proposed theoretical model

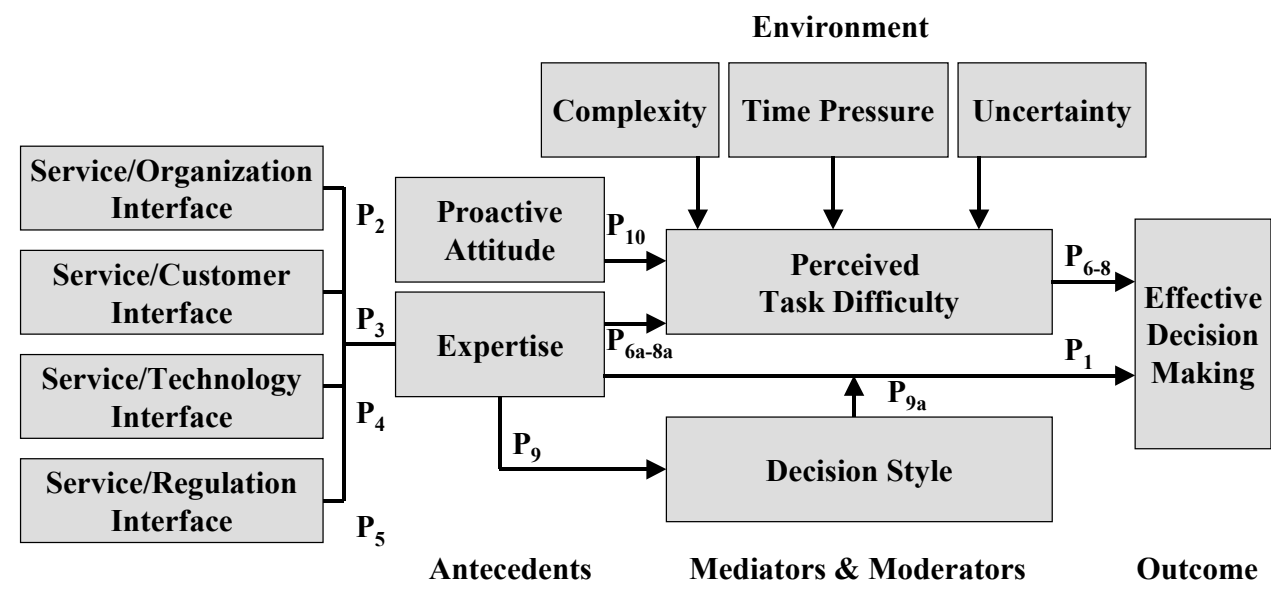




\section{References}

Ahlert, D. and Evanschitzky, H. (2002), "Erfolgsfaktoren von dienstleistungsnetzwerken: Theoretische grundlagen und empirische ergebnisse," in Bruhn, M. and Stauss, B. Eds), Dienstleistungsmanagement jahrbuch 2002: Electronic services, Gabler, Wiesbaden.

Baron, R.M. and Kenny, D.A. (1986), "The moderator-mediator variable distinction in social psychological research: Conceptual, strategic and statistical considerations", Journal of Personality and Social Psychology, Vol. 51 No. 6, pp. 1173-82.

Bateman, T.S. and Crant, M.J. (1999), "Proactive behavior: Meaning, impact and recommendations", Business Horizons, Vol. 42 No. 3, pp. 63-70.

Bayus, B.L., Jain, S., and Rao, A.G. (1997), "Too little, too early: Introduction timing and new product performance in the personal digital assistant industry", Journal of Marketing Research, Vol. 34 No. February, pp. 50-63.

Beach, L.R. and Mitchell, T.R. (1978), "A contingency model for the selection of decision strategies", Academy of Management Review, Vol. 4 No. pp. 439-49.

Behara, R.S. (2000), "Process innovation in knowledge-intensive services," in Fitzsimmons, M.J. (Ed.), New service development: Creating memorable experiences, Sage Publications Inc., Thousand Oaks, CA.

Bitner, M.J., Brown, S.W., and Meuter, M.L. (2000), "Technology infusion in service encounters", Journal of the Academy of Marketing Science, Vol. 28 No. 1, pp. 138-49.

Bogner, W.C. and Barr, P. (2000), "Making sense in hypercompetitive environments: A cognitive explanation for the persistence of high velocity competition", Organization Science, Vol. 11 No. 2, pp. 212-26.

Bonoma, T.V. (1985), "Case research in marketing: Opportunities, problems, and a process", Journal of Marketing Research, Vol. 22 No. May, pp. 199-208. 
Boone, T. (2000), "Exploring the link between product and process innovation in services," in Fitzsimmons, J.A. and Fitzsimmons, M.J. Eds), New service development: Creating memorable experiences, Sage Publications Inc., Thousand Oaks, CA.

Bourgeois III, L.J. and Eisenhardt, K.M. (1988), "Strategic decision processes in high velocity environments: Four cases in the microcomputer industry", Management Science, Vol. 34 No. pp. 816-35.

Burns, T. and Stalker, G.M. (2001), The management of innovation (Revised ed.), Oxford University Press, New York.

Burt, R.S. (1992), Structural holes: The social structure of competition, Harvard University Press, Cambridge MA.

Cohen, W.M. and Levinthal, D.A. (1990), "Absorptive capacity: A new perspective on learning and innovation", Administrative Science Quarterly, Vol. 35 No. pp. 128-52.

Cooper, R.G. (1992), "Stage gate systems for new product success", Marketing Management, Vol. 1 No. 4, pp. 20-29.

Cooper, R.G. and Edgett, S.J. (1996), "Critical success factors for new financial services: A stage-gate approach streamlines the new product development process", Marketing Management, Vol. 5 No. 3, pp. 26-37.

Cooper, R.G. and Kleinschmidt, E.J. (2000), "New product performance: What distinguishes the star products", Australian Journal of Management, Vol. 25 No. 1, pp. 17-45.

Cyert, R. and March, J. (1992), A behavioral theory of the firm (2nd ed.), Blackwell, Malden MA.

Dabholkar, P.A. (1996), "Consumer evaluations of new technology-based self-service options: An investigation of alternative models", International Journal of Research in Marketing, Vol. 13 No. 1, pp. 29-51.

Daft, R.L. and Lengel, R.H. (1986), "Organizational information requirements, media richness and structural design", Management Science, Vol. 32 No. 5, pp. 554-71.

D'Aveni, R.A. (1995), "Coping with hypercompetition: Utilizing the new 7s framework", Academy of Management Executive, Vol. 9 No. 3, pp. 45-57. 
---- (1994), Hypercompetition: Managing the dynamics of strategic maneuvering, Free Press, New York.

De Brentani, U. (1996), "Developing new business-to-business professional services: What factors impact performance?" Industrial Marketing Management, Vol. 25 No. 6, pp. 517-30.

Dutta, S., Narasimhan, O., and Rajiv, S. (1999), "Success in high-technology markets: Is marketing capability critical?" Marketing Science, Vol. 18 No. 4, pp. 547-68.

Easingwood, C.J. and Percival, J. (1990), "Evaluation of new financial services", International Journal of Bank Marketing, Vol. 8 No. 6, pp. 3-8.

Easingwood, C.J. and Storey, C. (1993), "Marketplace success factors for new financial services", Journal of Services Marketing, Vol. 7 No. 1, pp. 41-54.

Edvardsson, B., Haglund, L., and Mattsson, J. (1995), "Analysis, planning, improvisation and control in the development of new services", International Journal of Service Industry Management, Vol. 6 No. 2, pp. 24-35.

Eisenhardt, K.M. (1989), "Building theories from case study research", Academy of Management Review, Vol. 14 No. 4, pp. 532-50.

Froehle, C.M., Roth, A.V., Chase, R.B., and Voss, C.A. (2000), "Antecedents of new service development effectiveness: An exploratory examination of strategic operations choices", Journal of Service Research, Vol. 3 No. 1, pp. 3-17.

Hammond, K.R. (1996), Human judgment and social policy: Irreducible uncertainty, inevitable error, unavoidable injustice, Oxford University Press, New York.

Hastie, R. and Dawes, R.M. (2001), Rational choice in an uncertain world: The psychology of judgment and decision making, Sage Publications Inc., Thousand Oaks, CA.

Ittner, C.D. and Larcker, D.F. (1997), "Product development cycle time and organizational performance", Journal of Marketing Research, Vol. 34 No. 1, pp. 13-23.

Jensen, B. and Harmsen, H. (2001), "Implementation of success factors in new product development - the missing link", European Journal of Innovation Management, Vol. 4 No. 1, pp. 37-52. 
Johne, A. and Storey, C. (1998), "New service development: A review of the literature and annotated bibliography", European Journal of Marketing, Vol. 32 No. 3/4, pp. 184-251.

Judd, C.M., Smith, E.R., and Kidder, L.H. (1991), Research methods in social relations (6 ed.), Harcourt College Publishers, Forth Worth, TX.

Judge, W.Q. and Miller, A. (1991), "Antecedents and outcomes of decision speed in different environmental contexts", Academy of Management Journal, Vol. 34 No. 2, pp. 449-63.

Kerlinger, F.N. (1986), Foundations of behavioral research (3 ed.), Holt, Rinehart and Winston, New York.

Kessler, E.H. and Chakrabarti, A.K. (1996), "Innovation speed: A conceptual model of context, antecedents, and outcomes", Academy of Management Review, Vol. 21 No. 4, pp. 114391.

Lehmann, D.R. (1997), "A different game: Setting the stage", Working Paper, Report Nr. 97118, Marketing Science Institute, Cambridge, MA.

Lievens, A. (1996), "The antecedents and the role of communication during the innovation process of new financial services," Unpublished Ph.D. Thesis, Free University Brussels.

Lievens, A., De Ruyter, K., and Lemmink, J. (1999), "Learning during new banking service development: A communication network approach to marketing departments", Journal of Service Research, Vol. 2 No. 2, pp. 145-63.

Lievens, A. and Moenaert, R.K. (2000), "New service teams as information-processing systems: Reducing innovative uncertainty", Journal of Service Research, Vol. 3 No. 1, pp. 46-65.

Lovelock, C.H. (1984), "Developing and implementing new services," in George, W.R. and Marshall, C.E. Eds), Developing new services, American Marketing Association, Chicago, IL.

MacCormack, A. (2001), "Product-development practices that work: How internet companies build software", Sloan Management Review, Vol. 42 No. 2, pp. 75-84.

MacCormack, A., Verganti, R., and Iansiti, M. (2001), "Developing products on 'internet time': The anatomy of a flexible development process", Management Science, Vol. 47 No. 1, pp. $133-50$. 
March, J.G. (1978), "Bounded rationality, ambiguity, and the engineering of choice", The Bell Journal of Economics, Vol. 9 No. 2, pp. 587-610.

---- (1999), The pursuit of organizational intelligence, Blackwell Scientific Publishers, Maiden MA.

Martin, C.R. and Horne, D.A. (1995), "Level of success inputs for service innovations in the same firm", International Journal of Service Industry Management, Vol. 6 No. 4, pp. 40-56.

Menor, L.J., Tatikonda, M.V., and Sampson, S.E. (2002), "New service development: Areas for exploitation and exploration", Journal of Operations Management, Vol. 20 No. pp. 13557.

Meredith, J. (1993), "Theory building through conceptual methods", International Journal of Operations and Production Management, Vol. 13 No. 5, pp. 3-11.

Moorman, C. (1995), "Organizational market information processes: Cultural antecedents and new product outcomes", Journal of Marketing Research, Vol. 32 No. August, pp. 31835 .

Moorman, C. and Miner, A.S. (1998), "The convergence of planning and execution: Improvisation in new product development", Journal of Marketing, Vol. 62 No. 3, pp. 120.

Payne, J.W., Bettman, J.R., and Johnson, E.J. (1990), The adaptive decision maker: Effort and accuracy in choice, University of Chicago Press, Chicago, IL.

Schoemaker, P.J.H. (1982), "The expected utility model: Its variants, purposes, evidence and limitations", Journal of Economic Literature, Vol. 20 No. pp. 529-63.

Schumpeter, J.A. (1934), The theory of economic development, Harvard University Press, Cambridge MA.

Shapira, Z. (1997), "Introduction and overview," in Shapira, Z. (Ed.), Organizational decision making, Cambridge University Press, Cambridge.

Simon, H.A. (1997), Administrative behavior, a study of decision-making processes in administrative organizations (4th ed.), Free Press, New York. 
Storey, C. and Easingwood, C. (1998), "The augmented service offering: A conceptualization and study of its impact on new service success", Journal of Product Innovation Management, Vol. 15 No. pp. 335-51.

---- (1996), "Determinants of new product performance: A study in the financial services sector", International Journal of Service Industry Management, Vol. 7 No. 1, pp. 32-55.

---- (1993), "The impact of the new product development project on the success of financial services", The Services Industry Journal, Vol. 13 No. 3, pp. 40-54.

Stuart, F.I. and Tax, S.S. (1996), "Planning for service quality: An integrative approach", International Journal of Service Industry Management, Vol. 7 No. 4, pp. 58-77.

Sundbo, J. (1998), The organization of innovation in services, Roskilde University Press, Frederiksberg.

Tax, S.S. and Stuart, F.I. (1997), "Designing and implementing new services: The challenges of integrating service systems", Journal of Retailing, Vol. 73 No. 1, pp. 105-34.

Teale, M., Dispenza, V., Flynn, J., and Currie, D. (2003), Management decision-making towards an integrative approach, Pearson Education Ltd, Harlow.

Tushman, M.L. and Anderson, P. (1986), "Technological discontinuities and organizational environments", Administrative Science Quarterly, Vol. 31 No. September, pp. 439-65.

Tushman, M.L. and O'Reilly III, C.A. (1996), "Ambidextrous organizations: Managing evolutionary and revolutionary change", California Management Review, Vol. 38 No. 4, pp. 8-30.

Von Neumann, J. and Morgenstern, O. (1947), Theory of games and economic behavior, Princeton University Press, Princeton, NJ.

Weick, K.E. (2001a), Making sense of the organization, Blackwell Ltd., Oxford, UK.

---- (2001b), "Technology as equivoque: Sensemaking in new technologies," in Weick, K.E.

(Ed.), Making sense of the organization, Blackwell Publishers Ltd., Oxford.

Yin, R.K. (1993), Applications of case study research, Sage, Thousand Oaks, CA. 
---- (1994), Case study research: Design and methods (2nd ed.), Sage, Thousand Oaks, CA.

Zeithaml, V.A., Parasuraman, A., and Malhotra, A. (2000), "A conceptual framework for understanding e-service quality: Implications for future research and managerial practice", Working Paper, Report Nr. 00-115, Marketing Science Institute, Cambridge, MA. 